\title{
TINJAUAN TEOLOGIS TERHADAP PENDEKATAN EVIDENSIALIST DALAM PERSPEKTIF REFORMED THEOLOGY
}

\author{
Made Nopen Supriadi \\ madenopesupriadi@sttab.ac.id
}

\begin{abstract}
In the context of apolegetics known as the presupposition approach and evidentialist approach. However, many debates have led to disputes because of the overwhelming evidence that supports each other. Is it true that the defense of faith and the basis of faith always rest on evidence. Through this paper, we will explore a little about Reformed presuppositions as a theological review of the evidentialist approach.
\end{abstract}

Keywords: Overview, Theological, Approach, Evidentialist.

Abstraksi: Dalam konteks apolegetika dikenal dengan pendekatan presuposisi dan pendekatan evidensialist. Namun banyak perdebatan yang berujung pada pertikaian karena banyaknya bukti-bukti yang saling menguatkan. Apakah benar bahwa pembelaan iman dan dasar iman selalu bertumpu pada bukti. Melalui tulisan ini akan mengupas sedikit tentang presuposisi Reformed sebagai tinjauan teologis terhadap pendekatan evidensialist.

Kata Kunci: Tinjauan, Teologis, Pendekatan, Evidensialist.

\section{PENDAHULUAN}

Pandangan Eksklusif adalah pandangan yang menekankan sebuah kebenaran hanya terdapat dalam satu sumber dan sumber yang lain tidak benar. Pandangan eksklusifist bukanlah sebuah cara untuk memecah belah kehidupan tetapi sebuah sarana untuk mengetahui persepsi masing-masing kelompok. Namun muncul persoalan jika pandangan eksklusifist tersebut diterapkan dalam pendekatan terhadap kebenaran, salah satunya pendekatan evidensialist. ${ }^{1}$ Untuk dapat merumuskan pandangan ekslusifist dibutuhkan sebuah pendekatan, cara pendekatan tersebut dengan metode evidensilist. Metode evidensilist merupakan sebuah metode yang menekankan kecukupan argumen dan bukti untuk menjadikan sebuah keyakinan itu benar. ${ }^{2}$

Ronald H. Nash dalam bukunya Iman dan Akal Budi, menuliskan pernyataan seorang tokoh Evidensi sekular yang bernama W.K. Clifford, ia seorang Matematikawan pada abad 19 dalam bukunya "The Ethichs of Belief" menuliskan: "dimana saja, dan siapa

\footnotetext{
${ }^{1}$ Yakub Tri Handoko, Apologetika: Apa dan Bagaimana?, Reformed Exodus Community, diunggah pada 19 Desember 2015, pada situs http://rec.or.id/article_597_Apologetika-:-Apa-dan-Bagaimana?, diakses pada 20 Februari 2019

${ }^{2}$ Bdg. Dgn. Sutjipto Subeno "Banyak orang Kristen yang beranggapan bahwa presuposisi Kristen identik dengan teologi yang dipegangnya. Padahal tidaklah demikian. Presuposisi justru masih berada di belakang teologi (doktrin) yang dipegangnya. Mengapa seseorang lebih mau menerima teologi A ketimbang teologi B, disebabkan karena ia sudah mempunyai 'ancang-ancang' yang baginya lebih 'cocok' dengan teologi A, ketimbang teologi B.” (Lih. : Sutjipto Subeno, Presuposisi Teologi, Soteri, edisi 035/I/2003, diunggah pada situs https://reformed.sabda.org/node/40 diakses pada 20 Februari 2019)
} 
saja pasti salah bila meyakini segala sesuatu di atas evidensi yang tidak memadai". ${ }^{3}$ Jadi pendekatan evidensialist merupakan pendekatan yang selalu membutuhkan argumen dan bukti untuk menyatakan sebuah keyakinan itu benar.

Prinsip pendekatan evidensialist ini telah memberikan dua respon dalam kalangan Kristen, Thio Christian Sulistio menuliskan:

"Ada sebagian orang Kristen menerima pandangan evidensialisme ini dan berusaha menjawab tantangan tersebut dengan menunjukkan bahwa ada cukup bukti untuk keberadan Allah dan kepercayaan Kristen adalah Rasional. Mereka setuju dengan tuntutan evidensialisme bahwa sebuah kepercayaan harus memiliki bukti yang memadai jika hendak disebut rasional."

Jadi pendekatan evidensialist telah membagi keolompok Kristen ada yang menerima dan ada yang menolak, Ronald H. Nash menuliskan beberapa nama apologet yang memakai pendekatan evidensialist ialah R.C. Sproul, John H. Gerstner dan Arthur W. Lindsley. ${ }^{5}$ Selanjutnya muncul juga kelompok evidensialist yang teistik dan antiteistik. Kedua evidesialist tersebut memiliki penekanan yang berbeda dalam argumen, yaitu: Ronald menuliskan:

"Dalam tangan seorang evidensialis antiteistik, sebuah argumen bisa berbentu seperti ini: 1). Adalah tidak masuk akal untuk menerima keyakinan teistik tanpa adanya evidensi yang memadai. 2). Tak ada evidensi yang memadai untuk mendukung keyakinan kepada Allah. 3). Karena itu keyakinan kepada Allah adalah irrasional. Tapi ada juga sebagian besar evidensialis teistik yang memiliki garis argumen seperti ini: 1). Adalah tidak masuk akal untuk memberikan keyakinan teistik tanpa adanay evidensi yang memadai. 2). Ada evidensi yang memadai untuk mendukung keyakinan kepada Allah. 3). Karena itu keyakinan kepada Allah adalah rasional" 6

Jadi dengan demikian argumen dan bukti-bukti yang rasional menjadi standar adanya Allah. Thio menjelaskan kembali dasar pendekatan evidensialist secara filosofis:

"Pandangan evidensialisme ini berakar pada pandangan fondasionalisme klasik. Mereka berpendapat bahwa kepercayaan religius seperti kepercayaan kepada Allah bukanlah kepercayaan yang mendasar, sebab itu diperlukan bukti untuk menjadikannya terjustifikasi dan terjamin. Fondasionalisme klasik membagi kepercayaan menjadi kepercayaan mendasar (basic belief) dan kepercayaan tidak mendasar (non-basic belief)."7

\footnotetext{
${ }^{3}$ Ronald H. Nash, Iman dan Akal Budi, (Surabaya: Momentum, 2001), 106

${ }^{4}$ Thio Christian Sulistio, Epistemologi Reformed: Sebuah Upaya Filsuf-Filsuf Kristen Membela Status Epistemologis Kepercayaan Kristen, Jurnal Veritas 13/2, (Malang: SAAT, 2012), 219.

${ }^{5}$ Ronald H. Nash, Iman..., 106

${ }^{6}$ Ronald H. Nash, Iman ..., 106-107

${ }^{7}$ Thio Christian Sulistio, Epistemologi...,219
} 
Jadi menurut kelompok evidensialis membutuhkan dasar untuk membangun argumen dan bukti-bukti. Istilah kepercayaan mendasar (basic belief) adalah kepercayaan yang dipercayai tanpa bukti dari luar, hanya bukti dari dalam. Sehingga kepercayaan mendasar ini hanya bersumber dari diri manusia, berdasarkan indra manusia tanpa ada pengaruh dari luar. Kepercayaan tidak mendasar ialah bukti yang diberikan dari berbagai sumber dari luar diri manusia. Thio menuliskan bahwa kelompok evidensialis-fondalisme menyatakan bahwa kepercayaan religius tidak termasuk ke dalam kategori kepercayaan mendasar karena ia tidak terbukti dengan sendirinya dan tidak terbukti dengan indra kita. Oleh karena itu kepercayaan religius dimasukkan ke dalam kepercayaan tidak mendasar. ${ }^{8}$ Mari perhatikan skema berikut:
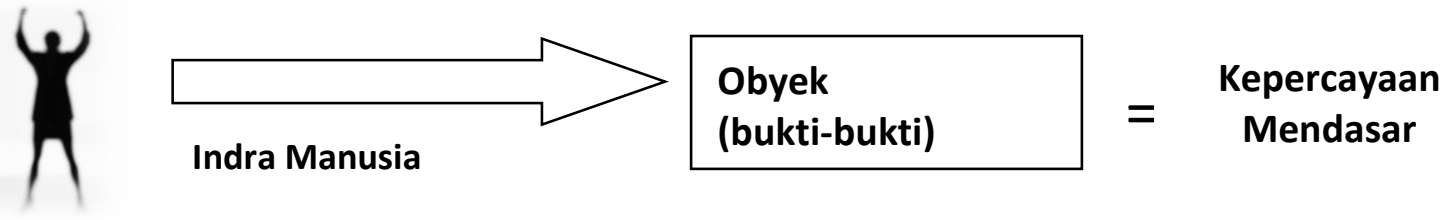

Jadi kepercayaan mendasar merupakan kepercayaan yang lahir dari bukti-bukti yang langsung didapatkan oleh penilaian panca indra manusia terhadap obyek yang bersangkutan.

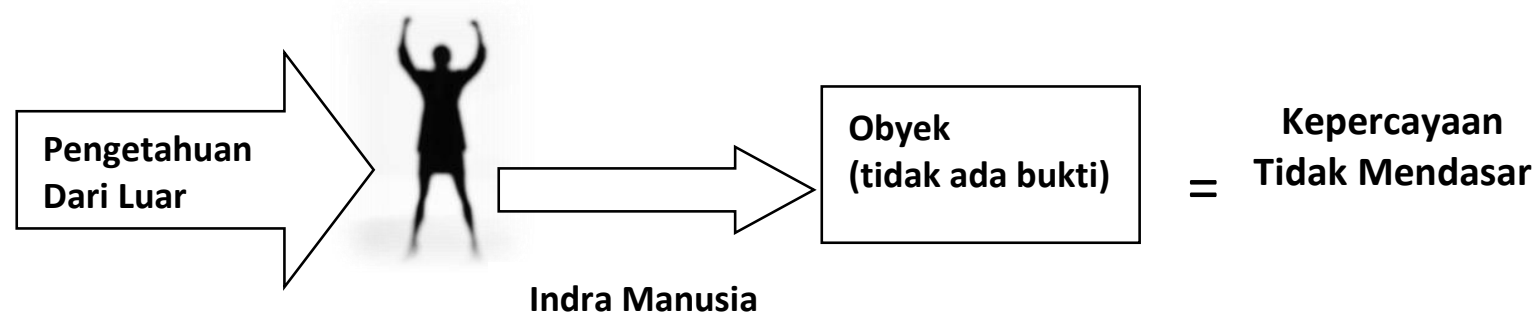

Jadi kepercayaan tidak mendasar merupakan kepercayaan yang lahir dari buktibukti yang didapat dari dari luar oleh indra manusia bukan dari obyek yang bersangkutan, oleh karena itu kepercayaan terhadap obyek tersebut tidak langsung tetapi baru percaya setelah dapat informasi dari luar. Menanggapi konsep di atas Thio menuliskan:

"menurut evidensialis-fondasionalis klasik, kepercayaan religius tidak termasuk ke dalam kategori kepercayaan mendasar karena ia tidak terbukti kepada indra kita. sebagai konsekuensinya, kepercayaan religius termasuk dalam kategori

${ }^{8}$ Ibid..., 219 
kepercayaan tidak mendasar dan oleh sebab itu harus mendasarkan dirinya kepada kepercayaan lain untuk mendapatkan justifikasi/jaminan"

Jadi pendekatan evidensialist menyimpulkan bahwa kepercayaan kepada Tuhan merupakan kepercayaan yang tidak mendasar. Oleh karena butuh bukti-bukti dari luar untuk bisa percaya kepada Tuhan, karena tidak ada bukti yang dapat ditangkap indra manusia dari yang disebut Tuhan (mata: tidak melihat Tuhan, Telinga: tidak mendengar Tuhan, Tangan: tidak bisa menyentuh Tuhan). Manusia bisa percaya kepada Tuhan karena ada pengetahuan dari luar indra manusia. Pada bagian ini pendekatan evidensialist telah melewati porsinya, jika evidensi diperlukan dimanakah posisinya? Pertanyaan ini akan dijawab pada bagaian selanjutnya.

\section{TINJAUAN TEOLOGIS THEOLOGI REFORMED TERHADAP PENDEKATAN EVIDENSIAL}

Seperti telah dipaparkan di atas ada kelompok yang setuju dengan pendekatan evidensi sehingga orang-orang yang percaya Tuhan berjuang keras mencari bukti adanya Tuhan. Namun Thio memberikan tanggapan yang berbeda dalam menanggapi pendekatan evidensialist dengan epsitemologi Reformed, ia tidak berupaya menyajikan bukti-bukti yang memadai tetapi berusaha untuk menantang asumsi evidensialist. ${ }^{10}$ Oleh karena itu dengan prinsip-prinsip Theologi Reformed akan memberikan evaluasi terhadap pendekatan evidensialist.

\section{a. Jawaban terhadap klaim pendekatan evidensialist yang menyatakan} kepercayaan kepada Tuhan merupakan kepercayaan yang tidak mendasar.

Pendekatan evidensialist menyatakan tidak ada informasi apa pun yang dapat ditangkap indera manusia tentang Tuhan. Plantinga mengembangkan sebuah teori warranted (jaminan). Plantinga menuliskan: "sebuah kepercayaan X terjamin (warranted), bila kepercayaan $\mathrm{X}$ tersebut dihasilkan oleh daya kognitif yang bertujuan untuk menghasilkan kebenaran”. Plantinga melanjutkan bahwa kepercayaan Kristen memenuhi jaminan (warranted) tersebut. Dalam Theologi Reformed dikenal sebuah istilah "sensus Divinitas" yaitu perasaan beragama. Sensu Divinitas (perasaan beragama) ini ada dalam diri manusia, jadi manusia pada indra kognitifnya sudah memiliki pengetahuan dan perasaan tentang Tuhan. Untuk lebih jelasnya perhatikan gambar berikut:

\footnotetext{
${ }^{9}$ Ibid..., 220

${ }^{10}$ Ibid..., 220
} 

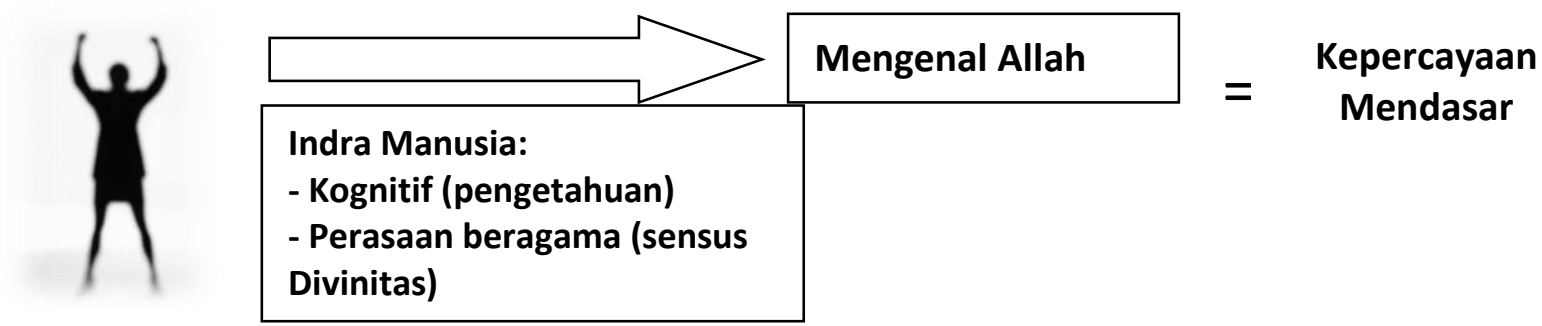

Jika dalam pendekatan evidensialist indra manusia tidak menangkap pengetahuan apap pun tentang Allah. Namun dalam epistemologi (teori pengetahuan) Reformed menyatakan bahwa natur indra bagian kognitif dan perasaan manusia telah memiliki pengetahuan tentang Tuhan, manusia telah mampu mengenal Tuhan. Lalu kenapa pendekatan evidensialist menyatakan indra manusia tidak bisa menangkap tentang Tuhan? Dalam Theologi Reformed ada istilah "total depravity" (kerusakan total) manusia tidak dapat mengetahui tentang Allah karena dosa telah merusak kognitif dan hati nurani manusia. Sehingga dosa merusak sensus Divinitas (perasaan beragama), kerusakan ini membuat manusia tidak dapat melihat dan mengenal Allah. Perhatikan gambar berikut:
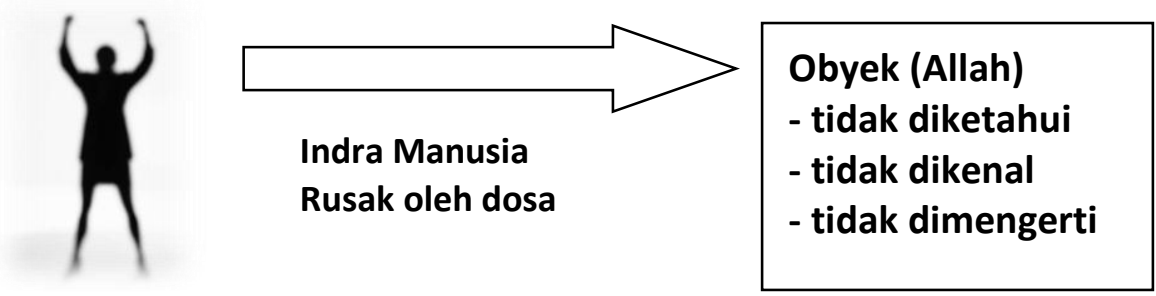

\section{Kepercayaan $=$ Tidak Mendasar}

Jadi kepercayaan dalam iman Kristen merupakan kepercayaan yang mendasar, karena dosalah maka manusia menjadikan kepercayaan dalam iman Kristen tidak mendasar. Teori pendekatan evidensialist ini merupakan teori yang dibuat dalam konteks kejatuhan rasio dalam dosa. Kejatuhan rasio manusia ke dalam dosa juga membuat manusia bisa menjadi atheis dan agnotis. Oleh karena itu dalam konteks masa kini jika Roh Kudus bekerja di dalam diri manusia, maka manusia tersebut akan mengalami kelahiran baru yang membuka hati dan pikiran manusia tentang Allah. Perhatikan gambar

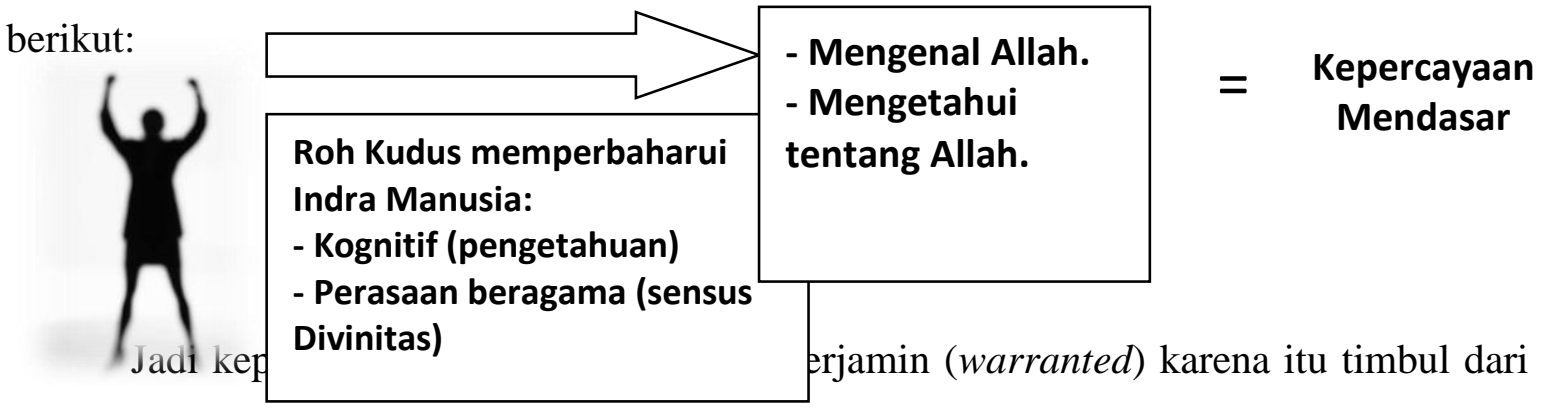
daya kognitif dan perasaan manusia yang ada dalam dirinya sendiri. Dan itu semua telah Allah berikan ke dalam diri manusia. Roh Kudus tidak menambahkan sesuatu pada 
kognitif dan perasaan manusia tetapi Roh Kudus memperbaharui daya kognitif dan perasaan beragama manusia sehingga memiliki pengetahuan tentang Allah yang benar. Mengenail hal tersebut Craig menuliskan:

"Kepercayaan Kristen yang dihasilkan melalui proses kesaksian internal Roh Kudus ini bukan kepercayaan Kristen yang bersifat Teologis mendalam seperti doktrin ineransi Alkitab, doktrin tentang dua natur Yesus Kristus, doktrin eskatologi amilenial, atau doktrin pemilihan infralapsarianisme. Tetapi kepercayaan yang dihasilkan adalah kepercayaan Kristen yang menjadi inti pengejaran keKristenan yang bersifat umum." 11

Jadi pembaharuan Roh Kudus membuat kognitif dan sensu Divinitas (perasaan beragama) menyadari kebenaran-kebenaran umum dalam iman Kristen, yaitu Allah menyelamatkan manusia berdosa melalui pengorbanan Yesus Kristus. Dengan demikian presuposisi pendekatan evidensialist merupakan pendekatan yang tidak konsisten, karena faktanya manusia tidak tahu apa-apa tentang Allah karena memang manusia tidak bisa memakai kognitif dan perasaannya terhadap Allah dalam keadaan berdosa.

\section{Apakah evidensi masih diperlukan dalam iman Kristen?}

Melanjutkan pernyataan Craig, jika kesaksian internal Roh Kudus cukup memberikan kebenaran umum dalam iman Kristen yaitu manusia diselamatkan dari dosa oleh Yesus Kristus. Namun dalam kehidupan orang Kristen perlu semakin dalam mengenal doktrin-doktrin. Namun kesaksian internal Roh Kudus merupakan kekuatan yang tidak dapat digoyahkan. Selanjutnya William L. Craig juga membuat sebuah pendekatan apologetika dengan membedakan anatar mengetahui Tuhan dan menunjukkan Tuhan.

Untuk mengetahui Tuhan, Craig menuliskan bahwa itu melalui kesaksian internal Roh Kudus. Stephen Tong, seorang tokoh Reformed di Indonesia menyatakan: "Roh Kudus memberikan kekuatan untuk meyakini sebuah kebenaran umum dalam iman Kristen yaitu Yesus adalah Tuhan". Kesaksian internal Roh Kudus inilah yang menjadi dasar (basic) manusia dapat mengetahui tentang Tuhan. Manusia memiliki pengetahuan tentang Tuhan selain dari kesaksian internal Roh Kudus juga dari argumen dan bukti-bukti. Namun argumen dan bukti-bukti itu hanya mengkonfirmasi, sedangkan Roh Kudus yang mengafirmasikan (menegaskan) itu adalah kebenaran. Karena itu untuk mengetahui

${ }^{11}$ William Lane Craig, Reasonable Faith: Christian Truth anda Apologetics, (Edisi 3), (Wheathon: Crossway, 2008), 43 
tentang Tuhan tanpa kesaksian internal Roh Kudus maka sia-sia. Karena manusia tidak dapat percaya sekalipun kata-kata yang indah dan logis diucapkan. ${ }^{12}$ Jika Roh Kudus berkarya maka manusia tersebut dapat percaya.

Untuk menunjukkan tentang Tuhan, maka manusia perlu memiliki evidensi (bukti). Jadi disinilah perlunya porsi pendekatan evindesi yaitu supaya manusia dapat menunjukkan apay yang telah diketahuinya. Evindesi (bukti) yang diimani hanya sebagai jembatan komunikasi untuk menyampaikan dengan tepat sesuai konteks apa yang telah diketahui. Evidensi ialah pengetahuan lanjutan (sekunder) dari pengetahuan utama (primer). Yang utama manusia tersebut harus mengetahui bahaw Iman Kristen benar dan selanjutnya harus menunjukkan kebenaran iman tersebut, karena itu manusia perlu belajar Kristologi, Pneumatologi, Ekllesiologi, Soteriologi dll. Perhatikanlah gambar berikut untuk emngetahui dimanakah posisi evidensi dalam membangun kepercayaan.

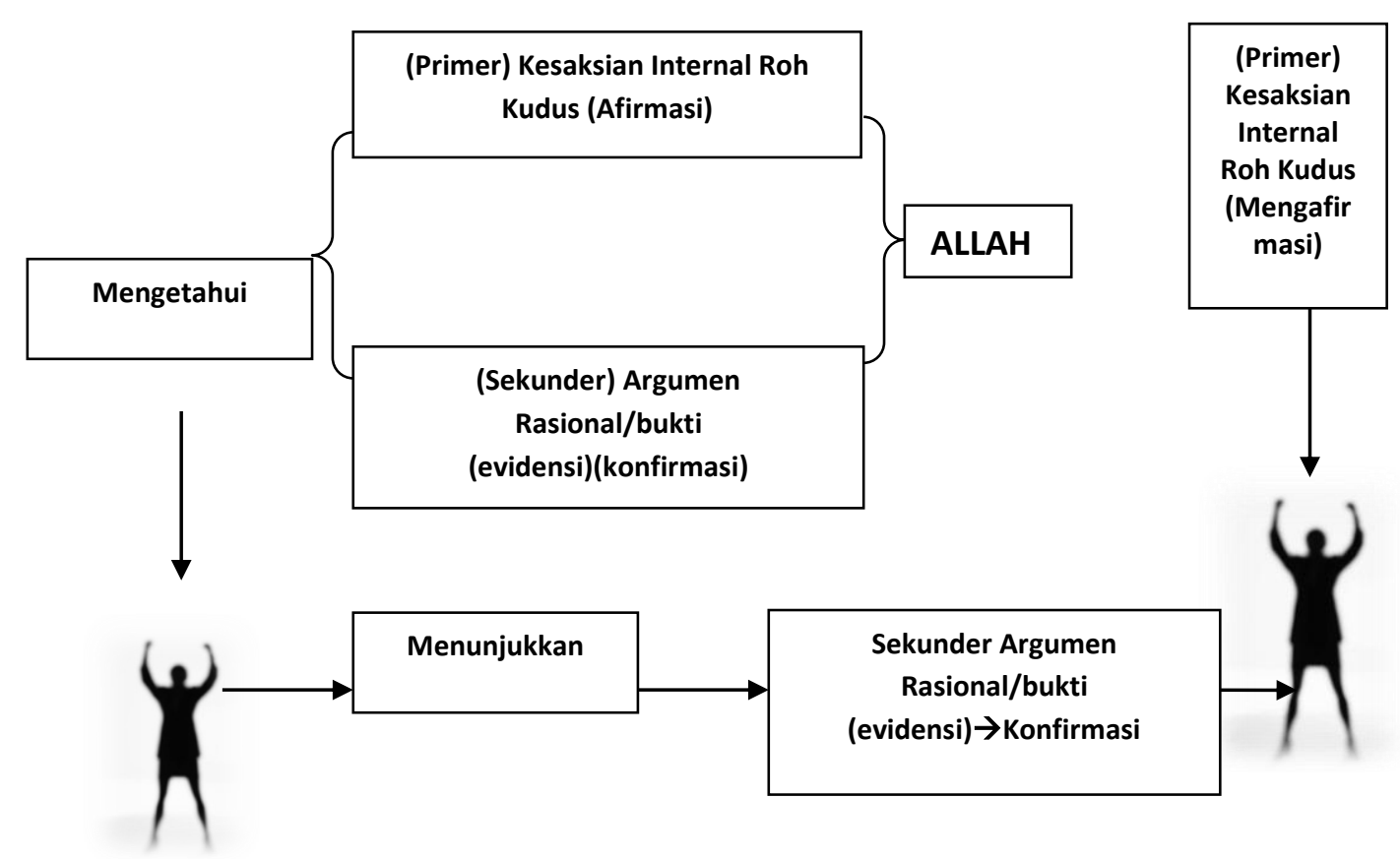

Dari gambar tersebut sangat jelas Theologi Reformed yang menjadikan Allah sebagi subyek juga obyek dalam iman Kristen. Allah Roh Kudus merupakan inisiator yang membawa manusia mengenal Allah dengan benar, dan juga Allah Roh Kudus menjadi dinamisator sehingga mendorong manusia untuk memperdalam imannya. Manusia mengetahui Allah karena Allah lebih dahulu membuka diri-Nya dan manusia menunjukkan tentang Allah kepada sesamanya karena Allah memberikan sebuah konsep

${ }^{12}$ Yohanes Calvin, Instituto (Jakarta: BPK. Gunung Mulia, 2012), 30 
keyakinan yang dapat dipertanggungjawabkan dan dengan kesaksian internal Roh Kudus akhirnya menegaskan kebenaran yang disaksikan.

\section{KESIMPULAN}

Pandangan Ekslusifist tidak sesuai dengan pernyataan Alkitab tentang iman Kristen. Karena pernyataan Alkitab bersifat universal, keeksklusifan dalam iman Kristen pada batas-batas untuk menunjukkan persepsi tentang bagaimana iman Kristen. Nilai-nilai Alkitab tidak eksklusif kepada orang Kristen tetapi segala manusia di bumi juga tetap berlaku hukum Allah. Keuniversalan tersebut terdapat dalam prinsip Theologi Reformed tentang mandat budaya dan mandat misi dalam kehidupan orang percaya, selanjutnya keuniversalan iman Kristen terlihat dalam penyataan umum. Lalu janji keselamatan yang mencakup seluruh bangsa di Bumi. Hal tersebut jelas menunjukkan iman kristen dalam konsep Theologi Reformed adalah konsep yang absolut dan universal. Memang benar dalam aplikasi keselamatan terlihat eksklusif karena ada manusia yang dipilih untuk diselamatkan dan dibinasakan tetapi keuniversalan tersebut juga terlihat dalam berita kesalamatn tersebut yang terus diberitakan sampai ke ujung bumi, hal tersebut bukan menunjukkan kontradiksi tetapi sebuah paradaoks dalam iman Kristen.

Evidensi tetap diperlukan dalam iman Kristen tetapi ada batasannya. Karena faktanya manusia diselamatkan oleh Anugerah Allah. Kesaksian internal Roh Kudus cukup membuat manusia mengenal konsep universal Allah yang menyelamatkan manusia. Orang yang disalib, bayi yang lahir cacat, orang yang ketinggalan mental mereka juga bisa diselamatkan oleh Tuhan, meskipun secara fisik mereka tidak mampu mencerna semua ajaran penting tentang iman Kristen. Namun karena kesaksian internal Roh Kudus yang membenahi konsep sensus Divinitas manusia membuat manusia dapat mengenal Allah yang benar di dalam Yesus Kristus. Evidensi diperlukan bukan untuk menyelamatkan manusia hanya untuk memberikan jawaban atas apa yang telah diketahui. Karena itu evidensi bisa menjadi alat Allah meyakinkan orang lain tetapi manusia tidak boleh berpikir evidensi bisa menyelamatkan orang lain. Karena sekalipun memiliki sejuta bukti iman tetapi jika Allah tidak memberikan iman maka sia-sialah bukti iman itu. Jadi kesaksian internal Roh Kudus dan Evindesi bermuara untuk memuliakan Allah. Soli Deo Gloria 


\section{DAFTAR PUSTAKA}

Calvin, Yohanes. (2012). Instituio, Jakarta: BPK. Gunung Mulia.

Craig, William Lane. (2008). Reasonable Faith: Christian Truth anda Apologetics, (Edisi 3), Wheathon: Crossway.

Handoko, Tri Yakub. (2015). Apologetika: Apa dan Bagaimana?, Reformed Exodus Community, diunggah pada 19 Desember, pada situs http://rec.or.id/article_597_Apologetika-:-Apa-dan-Bagaimana?.

Nash, Ronald H. (2001). Iman dan Akal Budi, Surabaya: Momentum.

Subeno, Sutjipto. (2003). Presuposisi Teologi, Soteri, edisi 035/I, diunggah pada situs https://reformed.sabda.org/node/40.

Sulistio, Thio Christian. (2012). Epistemologi Reformed: Sebuah Upaya Filsuf-Filsuf Kristen Membela Status Epistemologis Kepercayaan Kristen, Jurnal Veritas 13/2, Malang: SAAT. 